\title{
.Hotel Industry Regulations and Cross-Border Franchising: The Case of Saudi Arabia
}

\author{
Megbel Mishary Aleidan ${ }^{1}$ \\ ${ }^{1}$ Department of Management, School of Business, King Faisal University, Hofuf P. O. Box 380 Al-Ahsa, 31982, \\ Kingdom of Saudi Arabia. E-mail: maliedan@kfu.edu.sa
}

Received: June 22, 2017

Accepted: August 7, 2017

Online Published: August 12, 2017

doi:10.5539/ijbm.v12n9p94

URL: https://doi.org/10.5539/ijbm.v12n9p94

\begin{abstract}
Saudi Arabia has formulated and enforced a new tourism law to develop its tourism sector with special emphasis to open more international activities in the hotel industry. The main objective of this study was to determine the influence of new regulations of hotel industries in Saudi Arabia on the decision making process of the hotel companies in relation to international franchising. Qualitative research design was used to investigate the connection between new regulations of hotel industry in Saudi Arabia and its cross-border franchising activities. Data was retrieved from two primary sources: governmental agencies and, the hotel and leisure companies involved in franchising. The main sectors covered were the investment in tourism lands, establishment of tourism based associations, and replacement of foreigners, price and classification. Data was generated through twelve in-depth interviews with the representatives of the sample companies, from April to September 2016. The primary data generated during interviews was complemented by data from industrial publications and the annual reports to know about the current status of Saudi hotel industry and the activities of the sample companies. Findings confirmed that the regulatory reforms of a hotel industry, by following new hotel-based regulations, added new vigor to hotel based industry and enhanced its international profile. The new tourism law authorized the Saudi Commission for Tourism and Heritage (SCTH) to identify and propose new lands for tourism investment, which may increase its importance among the global hotels' franchisors.
\end{abstract}

Keywords: hotel industry, new hotel regulations, cross-border franchising, investment, tourism, foreigners

\section{Introduction}

Like many countries that seek reformative regulatory actions to revive their vital sectors, Saudi Arabia has also enforced a new tourism law to enhance the overall attractiveness of its tourism sector. As such, new law is expected to open the doors for more international activities, especially in the hotel industry. Previously, the presence of international franchisors in hotel industries in developing countries did not receive much attention of management researchers until the beginning of 1980s when Dunning and McQueen (1981) carried out an empirical assessment. Reluctance towards managerial research had been attributed to lack of awareness about regulation and policy-based research by the stakeholders of tourism sector in developing countries. Even until quite a recent time, tourism had not been considered notably for the purpose of research (Mycoo, 2016). Today, most of the international presence in hotel industries in the developing world is formed through cross-border franchising. Yet, the research contributions still appear to be meager regarding the impact of regulatory reforms on the inward franchising activities of the hotel industries in this part of the world.

The approach for reformation and regulation can be assessed in a better manner with the evaluation of studies concerning the franchising within the region of Saudi Arabia. Recently, Alharbi (2014) investigated the obstacles, faced by Saudi small and medium enterprises (SMEs); while franchising their brands. In another study, Asad Sadi \& Henderson (2011) highlighted the value of franchising for SMEs in Saudi Arabia and provided them with guidance for potential franchising activities in and outside the Saudi market. A study conducted by Martiz et al. (2007) also investigated franchising in Saudi Arabia by identifying the hurdles associated with franchising opportunities in the food market. These included lack of franchising-based regulations, access into qualified suppliers and non-availability of quality food materials. Earlier, Tuncalp (1991) conducted a study in Saudi Arabia on the problems and prospects for franchising in the Arabian Peninsula. The study reported fundamental difficulties, such as lack of franchising-based regulations and the collision between social faith of Saudis, and some franchising promotions and products, faced by international franchisors while doing business in Saudi 
Arabia.

The relationship between franchisee and franchisor can be examined from different theoretical perspectives. The study has opted agency theory to evaluate the strategic management of demands that are made by leaders. This type of trade-offs making has much to do with the applications of agency theory to the relationship of franchisee and franchisor. Dual distribution can be analysed in cost versus cost-trade-off plan. This approach argues that both company ownership and franchising have costs linked with them. When concerning the market demand and its associated impact, strategic decisions may influence several factors, including point of sale. The factors may also comprise of the level of services provided in an outlet for the customers and enhancing the value through their shopping experience. The franchisor's level of efforts is also one of the factor to streamline the supply chain. It may also enhance the reputation and image of the hotel for the customers (Marie Doherty et al., 2014).

The term franchising had never been used in a business context before the Middle Age. Linguistically, the word "franchising" has been derived from the obsolete French term "franche" that means "to free" or "to exempt" (Dicke, 2010). Basically, franchising is a contractual inter-firm business relationship that is formed between a grantee (franchisee) and a grantor (franchisor) for selling the franchisor's product, using the franchisor's trademark and proprietary business system in a specified location for a specified period of contract (Dant \& Grunhagen, 2014). In other words, it is "an economic relationship by which the owner of a product, a process or a trademark (the franchisor) grants the other party (the franchisee) a right to use them commercially for a fee or an agreed benefit" (Lewandowska, 2014). Both definitions imply that franchising is a dual system, in which the franchisor commercializes its product, process or trademark to the franchisee.

The agency theory, however, explains the purpose of franchising from its own perspective (Lafontine, 1992; Brickley \& Dark, 1987; Fama \& Jensen, 1983). According to the agency theory, a "moral hazard" is likely to occur in any agency relationship due to discrepancy between self-interests of two parties, mainly the principal and the agent (Eisenhardt, 1989; Jensen \& Meckling, 1976). It provides an opportunity to avoid moral hazards that may arise due to the fact that overall performance of the franchisor mainly depends on the performance of its franchisees (Bruton, Keels \& Scifres, 2002). Moreover, scarcity of resources considers franchising as an opportunity to ease the financial, administrative, and informational burdens encountered by investors in new geographical regions (Shane, 1996; Carney \& Gedajlovic, 1991; Craves \& Murphy, 1976).

Franchising not only eases the financial burden by securing scarce financial resources, but also affluences the administrative burden through leveraging the franchisee's administrative expertise. According to Lewandowska (2014), incentives, such as the exploitation of 'a successful business model', 'franchisor's reputation', 'franchisor's trade mark' and 'franchisor's network-wide advertising programs' are provided to buy the franchise. Industrial market has recognized franchising as the fast and secure path to enter international pools, gain foreign pervasiveness and currency and diminish the financial expenditures (Aydin \& Kacker, 1990).

From the perspective of different options of franchising strategies, namely the master franchising, regional master franchising, business format franchising, conversion franchising and joint venture, have been discussed (Chen, 2010; Garg \& Rasheed, 2006; Alon, 2006; Chan \& Justis, 1992; 1990). Statistically, it has been observed that franchisors tend to enter foreign markets through master franchising, joint venture franchising and conversion franchising (Welsh, Alaon \& Falbe, 2006). To account for the driving forces in international franchising, many factors; such as the success and failure of the franchisor's past experience in international markets, the age and the magnitude of the current franchising system were elaborated (Huszagh, Huszagh \& McIntyre, 1992). Moreover, saturation of the franchisor's local market had been considered crucial (Elango, 2007). As far as the international franchisor-franchisee relationship is concerned, issues related to the possible potential dispute between the two franchising parties and the expected managerial difficulties caused by the local franchisee and encountered by the franchisor had also are taken into account by various researchers (Szulanski \& Jensen, 2008; Paik \& Choi, 2007; Szulanski \& Jensen, 2006; Choo, 2005).

\subsection{Problem Statement}

Some studies have reported that many hurdles are associated with the franchising opportunities in Saudi Arabia's different industries, including the hotel industry. Non-availability of formal tourism and hotel associations and rigid franchising based regulations provoked the need to evaluate the connection between new regulations of hotel industry in Saudi Arabia and its cross-border franchising activities. Hotel industry regulations and cross-border franchising are essential to be investigated to maintain the level of hotels in the country. There was a gap in the literature concerned with hotel industry regulations and cross-border investment, so the study has evaluated the regulatory reform, which is required to appeal more global franchising in the Saudi hotel industry. Implications are needed to be evaluated that can be taken into account by the global hotel franchisors and the 
relevant regulatory authorities in Saudi Arabia.

\subsection{Significance of the Problem}

The inadequate investigations on the impact of regulatory reforms for franchising in Saudi Arabia, along with rare empirical studies in the rest of the developing world, encouraged the researcher to take a step further for investigating the role of new hotel regulations on the volume of franchising activities in the hotel industry. It has been presumed to add new vigor to the Saudi hotel industry by accelerating the pace of global franchising activities within it.

\subsection{Research Questions}

This study has aimed to determine the finding that may assist in finding answers to the following research questions:

1. Why regulatory reform is needed to lure more global franchising in the Saudi hotel industry?

2. Which aspects of the new regulations are critical for decisions made by the global hotel franchisors to enter the Saudi market or to expand their presence within it?

3. How does the global hotel companies evaluate these policy changes/amendments?

4. What implications can be taken into account by the global hotel franchisors and the relevant regulatory authorities in Saudi Arabia?

\subsection{Research Statement}

Until recently, the interest in hotel industry in Saudi Arabia has been influenced by a number of deformations mainly stemmed from the lack or absence of regulations. The transfer of hotel industry organization to the Saudi Commission for Tourism and Heritage (SCTH) has remarkably improved it by accounting 48 foreign franchisors within the region. The improvement in increasing the foreign franchisors mainly occurs due to increased confidence of the foreign franchisors in the SCTH's ability to modernize the industrial regulations. These regulations have formed the basis of new Saudi tourism law issued during 2014. These laws showed substantial increase in the number of international investments at the corporate, business, industrial and religious levels. These regulations enabled the promotion of Riyadh as a corporate hub of global hotels franchisors; 5 -stars hotels account for the largest portion of the city (Capital, 2015). New regulations have also promoted the industry within different regions of Saudi Arabia by 4-5 stars hotel industry. Such momentum is known to push the current approaches to make an attempt to comprehend the influence of new regulations of hotel industries in the host country, Saudi Arabia, on the decision making process of the hotel companies in relation to international franchising and thus, the idea has been adopted as the objective of this study. The study found it essential to evaluate the findings by focusing on four themes made for the study including investment of tourism land, establishment of tourism-based associations, replacement of foreigners and price and classification. The issues regarding these four themes assisted the study to approach the requirements from the perspective of participants included in the study.

\section{Methodology}

The study has opted qualitative research design and used deductive approach to evaluate the study findings. Since the present study is an industry-based case study, a qualitative mode of investigation, as described by Lincoln \& Guba (1985), has been used to investigate the connection between new regulations of hotel industry in Saudi Arabia and its cross-border franchising activities. Another catalyst for adopting; such qualitative mode, has been found to be associated with the exploratory nature of the study (Lee, 1999; Miles \& Huberman, 1994); it has been comprehending the influence of new hotel regulations in Saudi Arabia on the decision making process of the hotel companies in relation to the international franchising.

\subsection{Inclusion Criteria}

Two primary sampling criteria were identified: (1) governmental agencies that have been administrating and regulating the hotel industry of Saudi Arabia, and (2) the hotel and leisure companies, which have been recently involved in franchising either to invest in the Saudi hotel industry for the first time or to boost their existing investment. The latter criterion assured that all the sample companies (franchise providers) have been positively or negatively influenced by the newly issued tourism law, promulgated by Royal Decree No. 2, dated 25 October 2014. The former criterion was used to understand the new regulations, affecting the hotel industry of Saudi Arabia and the motives behind its enactments.

\subsection{Sampling for Data Collection}

Data was initially generated through four in-depth interviews with SCTH's key employees during a visit to their 
premises in Riyadh, Saudi Arabia, in 2016. 4 interviews were conducted with the SCTH and 12 with the three hotels overall. 4 interviews were conducted with each hotel company, which lasted for almost 60 to 90 minutes. All the interviews were conducted on one-on-one meetings. The interviews included the questions regarding the themes made for the study. The interviews were conducted by the research specialists and they took the interviews in English as well as in Arabic language depending upon the language understandable by the interviewee. The themes included were investment of tourism land, establishment of tourism-based associations, replacement of foreigners and price and classification. The aim was to understand the impact of new Saudi hotel industry regulations on the relevant cross-border franchising from the industry regulator's perspective. These interviews were followed by a number of semi-structured interviews with top management members of three hotels and hospitality franchisors at their domestic (within Saudi Arabia) or regional (within the Middle East) offices. For generating rich and relevant data, the interviewees were selected according to their engagement in the cross-border franchising decision-making process of the country of choice. This procedure ensured that all the interviewees held similar positions at the sample companies and possess comparable experiences with respect to cross-border franchising. The interviewees of the sample companies were asked to provide details of their operations within the Saudi hotel industry and about the extent to which these operations are likely to be affected by the new regulations of the industry.

\subsection{Research Approach}

Altogether, 12 interviews were conducted with the representatives of the sample companies from April to September 2016. The primary data generated during interviews was complemented by data from industrial publications and the annual reports to determine the current status of Saudi hotel industry and the activities of the sample companies. Thematic analysis based on the findings of Braun \& Clarke (2006) was used to assign specific themes to the data with the representatives of the sample companies. The rationale behind the use of such analysis was its capacity to detect distinct patterns in the forms of themes, present within the data, generated during the interviews with the possibility of interpreting different aspects of the connection between the regulations of hotel industry in Saudi Arabia and its cross-border franchising activities (Boyatzis, 1998). Accordingly, four themes were extracted from the current research's data set based on their relevance to its topic. The themes included:

I. Investment of tourism lands,

II. Establishment of tourism-based associations,

III. Removal of outsiders,

IV. Prices and classification.

\section{Results}

As per the sampling criteria and in accordance to the four themes identified, an industry-based case study was formed to explore the connection between the regulations of the hotel industry in Saudi Arabia and the cross-border franchising activities within it.

\subsection{Investment of Tourism Lands}

It is obvious that the global hotel companies, operating in Saudi Arabia, are trying to gain their best in terms of investment in tourism through newly enacted hotel regulations. Global hotel franchisors are thus, welcoming such regulations, as they grant the SCTH with full authority to propose governmental lands for tourism, especially for hotel investment purposes. The approach is justified with the emphasis that SCTH is a reliable decision making entity and an assessor of tourism lands with richer relevant knowledge in comparison with other governmental bodies that have been previously engaged in the process of land proposals and tourism investments. The global hotel franchisors explicitly express their confidence in the tourism authorities (SCTH and its affiliates) as the latter are able to propose lands more wisely. They appear to comprehend the type of investments and lands that encourage hotel owners and franchisors to set up new conducts. These may include new hotel proposals, property lease or a property management contract.

Revamping of tourism laws have been noted to strengthen SCTH with the matters of tourism and provides with the opportunity to explore more of Saudi Arabia, especially, the cities with immature tourism and hotel development. Major characters of Saudi hotel industry specifically highlight places like Uqair, in the city of Hofuf, and Sharma, in the city Tabuk, as potential destinations for further hotel investments. It has been emphasized that contribution of new tourism law in promoting such places can further enhance the economic status of the country. The global hotel franchisors believe that, as SCTH is accountable for developing the entire tourism system of Saudi Arabia, they are the only authority that can proactively identify the locations of interest. This implies that the SCTH can appropriately propose lands for hotels development in consistency with other 
elements of tourism system like restaurants, entertainment centers, shopping malls and others.

\subsection{Establishment of Tourism-Based Associations}

With the potential development of tourism industry in Saudi Arabia, the need for industry intra-relationships has been noted to increase. The new tourism law of Saudi Arabia has paved way for strengthening such relationships by enabling SCTH to form tourism-based associations. The icons of tourism industry in Saudi Arabia (hotels, tour operators, travel agencies, marketing representation companies, restaurants, entertainment centers, amusement parks, folklore shows, cruises companies, transport providers) are currently involved in connecting informally and beyond the boundaries of a formal body.

The global hotel franchisors have been found to be optimistic and believe that the establishment of tourism-based associations will replace the informal relationships by formal and solid ones. As such, it will enable them to extrapolate the industrial data and make assumptions for long run within the industry. With its ability to generate permanent networking opportunities, these associations will be considered by global hotel franchisors as a mechanism to recruit Saudi hoteliers with high potential hotel-keeping skills. These skills may include the attributes of managing a well-maintained hotel, meeting guests' expectations, developing new services and reinforcing the potential of other hoteliers. Such associations also represented the voice of hotel industry's companies, notably as they result in generating cooperative actions between the two dominant powers of the industry (government and industry's companies). Examples of these actions can be the identification of methods to work closely with SCTH on formulating new policies of the hotel industry, proposing ways to promote the Saudi hotel industry, generating new hotel-based knowledge with the sharing possibility and organizing hotel-based events in the forms of forums, conferences, awards, workshops, seminars and so on. The global hotel companies therefore, appear keen to be represented in the steering committees of such associations.

\subsection{Replacement of Foreigners}

As a mechanism to combat illegal competition within the Saudi hotel industry, new hotel regulations have been oriented to replace strangers from the industry. Parties providing illegal housing/accommodation services are considered the strangers in tourism business. The global hotel companies express a view that the rigorous licensing system, emanating from the new regulations, is an entry constraint to the foreigners. It can act as a reformer of the Saudi hotel industry's current distortions, which substantially affect the industry's attractiveness. It is being expected that the new licensing system will restructure the industry through suppressing the rise of the outsiders. Although, global hotel companies admit that they are not being preempted by the foreigners for invading the Saudi tourism market, because of their personation and 5-stars capabilities. They believe that the vacant rooms can be filled by their second tier brands or the 4-stars hotels. They have also deemed that in case these foreigners cling to remain in the market, they will be enforced to renovate themselves in a radical way to comply with the new licensing system. Eventually, they will transform from outsiders of the industries to insiders. An example of such shift can be found in some apartments that have been humble and non-professionally designed but were later turned into hotel apartments with professional managerial services, as per the enforcement of new licensing system. Although, the global hotel companies prefer to replace the foreigners from the industry due to exploitation and expansion purposes, they still appear to encourage the shift of domestic modalities into professionally managed accommodations. Many icons have been identified that have observed this as an ultimate goal. The approach has been increasing the attractiveness of the industry that can be attained from both of the cases.

The global hotel franchisors are also paying importance to the urgency associated with the new regulations to establish a national tourism center in Saudi Arabia. They believe that the existence of such center can and will provide them with detailed information about the coming and the leaving characters within and from the industry. It is presumed that with these information made available to the global hotel franchisors, their willingness to plug the gap within the industry will be increased.

\subsection{Price and Classification}

The global hotel companies emphasize that the new hotel regulations can establish the principle of parity and equality for the price identification. The approach is known to urge SCTH to identify comparable prices for comparable hotel services. Yearly-based price identification regulations are considered an obstacle against price manipulation and price hiding, especially in the light of increasing discontent with the prices of hotel services. The global hotel companies argue that with yearly proactive identification of the hotels' services, prices during the periods of mid-week, week-end and seasons, mutual transparency can be fostered between the providers and the recipients of hotel services. They also acknowledged the contribution of new regulations in combating clandestine coalition that can be formed by the influential players of the industry. This can be attained to increase 
services prices as these regulations may criminalize behaviors and lead to fine the perpetrators for up to SR 10 million. With the acknowledgment of what the new price-related regulations entail in terms of eliminating price manipulation and hiding, boosting transparency and combating illegal price increases lobbying. Global hotel companies still have reservations over the collision between these regulations and their premium pricing policy. The collision has emerged from the SCHT's identification of specific maximum value that might not be consistent with some of their prestigious services.

Global hotel companies are encouraged by the newly launched classification system of SCHT, as they perceive the underlying marketing impact by considering it as an extension to increase brand awareness and distinguishing rivalries within the industry. The approach is either optional or compulsory; the global hotel companies are willing to take part in the classification process with utmost confidence that they will fulfill the classification requirements. With the recognition of the classification system's contribution in distinguishing the hotels according to the quality of their services, global hotel companies seek further form of discrimination. These conducts appear to be in need of categorization according to their specialty: corporate hotels, airport hotels, resort hotels, extended stay hotels, etc. There have been many concerns raised about the issuing process of classification certificates. The main concern has been the burden of bureaucracy and officials that can be imposed on issuing the process of classifications with high transaction costs.

\section{Discussion}

Findings of the study have offered first-hand evidence to confirm the regulatory reforms of hotel industry by following new hotel-based regulations. These elements are believed to add potency to the industry and enhance its international profile. They have also stated that such enhancement can be achieved by tourism-based governmental agencies (including those accountable for regulating hotels) by meeting the expectations of industry's stakeholders (including global hotel franchisors). These findings are in line with the ideas of Lew, Hall $\&$ Williams (2008), who highlighted the probable role of government in promoting tourism. They have perceived that "the role of government in tourism has undergone a dramatic shift from a traditional public administration model to a corporatist model thus emphasizing the efficiency, investment returns, the role of the market, and relations with stakeholders, usually defined as industry". The study findings also identified four aspects that are commonly perceived by the global hotel companies as concrete advantages of the new hotel regulations. Basically, these are related to investment of tourism lands, establishment of tourism-based associations, removal of outsiders and price and classification.

New tourism law authorizes SCTH to identify and propose more lands for tourism investments; thus, increasing its importance for the global hotels' franchisors. Consequently, those franchisors are trusted to urge the current and potential local franchisees to maintain and enhance ties with SCTH. It will enable them to seize the most favorable investment opportunities provided by the SCTH. Such ties can be enhanced by constant contact with the Department of Touristic Investment and Development of SCTH for exploring new investment hotel opportunities, delegating a representative to attend the SCTH's conferences, meetings and workshops. Such practices can address the investment within the hotel industry, seeking customized counseling services from the SCTH's experts on the selection of hotel sites and schemes and leveraging the power of SCTH to negotiate the acquisition of lands from some governmental agencies. These business-government ties prefer the global hotel companies and their local partners (if any) to adopt a more pragmatic approach while dealing with the related governmental agencies. The pragmatism can be defined as the mutual dependence between two parties and co-production rather than collaboration regardless of the differences of their roles (Hughes \& O'Neill, 2008).

With the contribution of new tourism law in promoting places outside the cities of Riyadh, Jeddah and Dammam as well as the two holy cities, it has been made imperative for the global hotel companies to extend their screening processes within the Saudi market. It has been identified that these factors are keen to explore more locations in Saudi Arabia by developing their relationships with local municipalities and regional offices of SCTH for seizing any upcoming opportunities. The early perception of local municipality's tourism schemes have been considered to assist the global hotel companies with expansion strategy in Saudi Arabia. Thus, as per the authority of SCTH to propose lands for tourism investments, the global hotel companies and their local partners (if any) should consider a broad picture while negotiating any investment possibilities with SCTH.

Given the encouragement by the new tourism law for the establishment of tourism-based associations, the global hotel companies and their local partners (if any) should exploit such associations in facilitating information sharing, counseling, training and industry-government collaboration. The members of the tourism-based associations with empowered knowledge capabilities can better understand the changes of their industry and acclimate themselves accordingly (Cruz, Hamilton \& Jack, 2012). Furthermore, it has been determined that the 
formalization of tourism industry in response to tourism-based associations can lead to the emergence of new and constant arenas for intra-industrial cooperation. One aspect of such cooperation, which can be availed by the global hotel companies, is to outsource some of their value added activities to the non-hotel members within the associations. From another perspective, these associations are expected to act as a platform for hotel-based jobs. Members of such associations, including global hotel companies, said to jointly organize open days to recruit Saudi hoteliers.

In order to enjoy a more monopolistic position in Saudi hotel industry, global companies are encouraged to take advantages of the vacancies left by the foreigners in hotel industry by pursing further expansion. The exit of such foreigners from the hotel industry can be observed as a corrective mechanism, provided the high possibility of being beaten by larger and global competitors (Fornell \& Wernerfelt, 1987). It has been seen that the competition of foreigner bodies with bigger rivals, including the international ones, can majorly affect stature in market; thus, influencing their exit and entry from and into the industry (Kim, Bridges \& Srivastava, 1999). Departure of foreigners can also be interpreted as an attempt to avoid harnessing of resources in investment for change (Karakaya, 2000). Consequently, movement of these foreigners from the industry and the expansion strategies of the global hotel franchisors alongside their local partners within Saudi Arabia should be considered as the investment opportunities. Specifically, global companies with the ability to offer 4-stars franchising opportunities can leverage the vacuum by providing an alternative option. The option can benefit those customers, who may have average financial capability. It can provide them with substantially improved services in comparison with the services previously provided by the foreigners. The call for new tourism law for establishing a national tourism center can further assist the global hotel companies to exploit the departure of foreigners from the industry by providing them with data in the forms of industry's reports, policy reports and others. However, the success of such centers cannot be considered dependable as SCTH constantly updates the information pool and facilitates the access of companies, including the global ones.

Despite the positive effects of the new hotel regulations, yearly identification of price ceiling on price manipulation, price hiding, and transparency, it still tends to overwhelm the industrial icons including the global ones with some challenges. As an alternative to price wars, hotel companies in Saudi Arabia, especially global ones, are expected to exercise services as a discrimination mechanism. Each company is expected to exert increased efforts for enhancing its current package of services or initiating new services to hinder its competitors from intruding. The capability of a company to introduce new services can be blocked by others, who strategically manage to offer quality services just before the launch of that company's service (Siebert, 2015). The approach implies that the race for initiating better services in Saudi hotel industry might intensify in the near future. It also suggests that the adoption of service innovation culture with coherent principles may further stimulate creativity and rapid implementation (Lyons, Chatman \& Joyce, 2007). It is a prerequisite for global hotel companies to distinguish themselves within the Saudi market. Therefore, these companies should put emphasis on employees-based processes like maintaining energetic and friendly behavior (Sethi \& Nicholson, 2001). Such measures are known to promote innovation among the peers. Concerning the classification, global hotel companies should be among the first to undergo the classification process established by SCTH, as it contributes to the high potential and most likely influence the customer' preference. Johansson and Ronkainen (2005) claimed that brand esteem is affected by classification and categorization. The high potential classification should be used as a marketing weapon by these companies for battling against the local competitors. The marketing weapon of the local market tends to be more concentrated on symbolic values derived from the local culture and ethnocentric orientations of customers (Xie, Batra \& Peng, 2015). Brand awareness of global hotel companies in the Saudi market can be further enhanced by merging SCTH's classification with global ranking, where they usually present as local counterparts. Finally, SCTH should use its classification process for ranking the hotel companies and rewarding those with superior performances to encourage others for improvement.

\section{Acknowledgements}

The author is very thankful to all the associated personnel in any reference that contributed in/for the purpose of this research. This research holds no conflict of interest and is not funded through any source.

\section{References}

Alharbi, M. M. (2014). Barriers to franchising in Saudi Arabia. Journal of Marketing Channels, 21(3), 196-209 http://dx.doi.org/10.1080/1046669X.2014.913218.

Alon, I. (2006). Market conditions favoring master international franchising. Multinational Business Review, 14(2), 67-82. https://doi.org/10.1108/1525383X200600009 
Asad Sadi, M., \& Henderson, J. C. (2011). Franchising and small medium-sized enterprises (SMEs) in industrializing economies: A Saudi Arabian perspective. Journal of Management Development, 30(4), 402-412. https://doi.org/10.1108/02621711111126855

Aydin, N., \& Kacker, M. (1990). International outlook of US-based franchisers. International Marketing Review, 7(2). https://doi.org/10.1108/02651339010143381

Boyatzis, R. E. (1998). Transforming qualitative information: Thematic analysis and code development.

Braun, V., \& Clarke, V. (2006). Using thematic analysis in psychology. Qualitative research in psychology, 3(2), $77-101$.

Brickley, J. A., \& Dark, F. H. (1987). The choice of organizational form the case of franchising. Journal of Financial Economics, 18(2), 401-420. https://doi.org/10.1016/0304-405X(87)90046-8

Bruton, G. D., Keels, J. K., \& Scifres, E. L. (2002). Corporate restructuring and performance: an agency perspective on the complete buyout cycle. Journal of Business Research, 55(9), 709-724. https://doi.org/10.1016/S0148-2963(00)00212-5

Capital, A. (2015). Saudi hospitality sector report.

Carney, M., \& Gedajlovic, E. (1991). Vertical integration in franchise systems: Agency theory and resource explanations. Strategic Management Journal, 12(8), 607-629. DOI: 10.1002/smj.4250120804

Caves, R. E., \& Murphy, W. F. (1976). Franchising: Firms, markets, and intangible assets. Southern Economic Journal, 572-586. http://dx.doi.org/10.2307/1056250

Chan, P. S., \& Justis, R. T. (1990). Franchise Management in East Asia. The Executive, 4(2), 75-85. http://dx.doi.org/10.5465/AME.1990.4274799

Chan, P. S., \& Justis, R. T. (1992). Franchising in the EC: 1992 and beyond. Journal of Small Business Management, 30(1), 83.

Chen, H. H. (2010). The explanations of agency theory on international multi-unit franchising in the Taiwanese marketplace. International Journal of Organizational Innovation (Online), 3(1), 53.

Choo, S. (2005). Determinants of monitoring capabilities in international franchising: foodservice firms within East Asia. Asia Pacific Journal of Management, 22(2), 159-177. http://dx.doi.org/10.1007/s10490-005-1253-1

Cruz, A. D., Hamilton, E., \& Jack, S. L. (2012). Understanding entrepreneurial cultures in family businesses: A study of family entrepreneurial teams in Honduras. Journal of Family Business Strategy, 3(3), 147-161. https://doi.org/10.1016/j.jfbs.2012.05.002

Dant, R. P., \& Grünhagen, M. (2014). International franchising research: Some thoughts on the what, where,

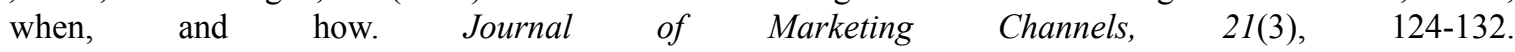
http://dx.doi.org/10.1080/1046669X.2014.917012

Dicke, T. S. (1992). Franchising in America: the development of a business method, 1840-1980. UNC Press Books.

Dunning, J. H., \& McQueen, M. (1981). The eclectic theory of international production: a case study of the international hotel industry. Managerial and decision economics, 2(4), 197-210. http://dx.doi.org/10.1002/mde.4090020401

Eisenhardt, K. M. (1989). Agency theory: An assessment and review. Academy of management review, 14(1), 57-74. http://dx.doi.org/10.5465/AMR.1989.4279003

Elango, B. (2007). Are franchisors with international operations different from those who are domestic market oriented? Journal of Small Business Management, 45(2), 179-193. http://dx.doi.org/10.1111/j.1540-627X.2007.00208.x

Fama, E. F., \& Jensen, M. C. (1983). Agency problems and residual claims. The Journal of Law and Economics, 26(2), 327-349. https://doi.org/10.1086/467038

Fornell, C., \& Wernerfelt, B. (1987). Defensive marketing strategy by customer complaint management: a theoretical analysis. Journal of Marketing research, 337-346. http://dx.doi.org/10.2307/3151381

Garg, V. K., \& Rasheed, A. A. (2006). An Explanation of International Franchisors' Preference for Multi-Unit Franchising. International Journal of Entrepreneurship, 10, 1. 
Hughes, O. E., \& O’Neill, D. (2008). Business, government and globalization. Palgrave Macmillan.

Huszagh, S. M., Huszagh, F. W., \& McIntyre, F. S. (1992). International Franchising in the Context of Competitive Strategy and the Theory of the Firm. International Marketing Review, 9(5). https://doi.org/10.1108/02651339210020268

Jensen, M. C., \& Meckling, W. H. (1976). Theory of the firm: Managerial behavior, agency costs and ownership structure. Journal of Financial Economics, 3(4), 305-360. https://doi.org/10.1016/0304-405X(76)90026-X

Johansson, J. K., \& Ronkainen, I. A. (2005). The esteem of global brands. Journal of Brand Management, 12(5), 339-354. http://dx.doi.org/10.1057/palgrave.bm.2540230

Karakaya, F. (2000). Market exit and barriers to exit: Theory and practice. Psychology \& Marketing, 17(8), 651-668. http://dx.doi.org/10.1002/1520-6793(200008)17:8<651::AID-MAR1>3.0.CO;2-K

Kim, N., Bridges, E., \& Srivastava, R. K. (1999). A simultaneous model for innovative product categorysales diffusion and competitive dynamics. International Journal of Research in Marketing, 16(2), 95-111. https://doi.org/10.1016/S0167-8116(98)00026-3

Lafontaine, F. (1992). Agency theory and franchising: some empirical results. The RAND Journal of Economics, 263-283.

Lee, T. W. (1999). Using qualitative methods in organizational research. Sage.

Lew, A. A., Hall, C. M., \& Williams, A. M. (Eds.). (2008). A companion to tourism. John Wiley \& Sons.

Lewandowska, L. (2014). Franchising as a way of creating entrepreneurship and innovation. Comparative Economic Research, 17(3), 163-181. https://doi.org/10.2478/cer-2014-0028

Lincoln, Y. S., \& Guba, E. G. (1985). Naturalistic inguig. Beverly Hills: Sage.

Lyons, R. K., Chatman, J. A., \& Joyce, C. K. (2007). Innovation in services: Corporate culture and investment banking. California management review, 50(1), 174-191. http://dx.doi.org/10.2307/41166422

Marie Doherty, A., Chen, X., \& Alexander, N. (2014). The franchise relationship in China: agency and institutional theory perspectives. European Journal of Marketing, 48(9/10), 1664-1689. http://dx.doi.org/10.19030/jber.v4i4.2652

Maritz, A., Abughazala, H., \& Frederick, H. (2007, January). Entrepreneurial market entry: A franchising perspective in Saudi Arabia. In AGSE 2007: Regional frontiers of entrepreneurship research 2007: Proceedings of the 4th Regional Frontiers of Entrepreneurship Research conference, 2007 (pp. 652-653). AGSE.

Miles, M. B., \& Huberman, A. M. (1994). Qualitative data analysis: An expanded sourcebook.

Mycoo, M. (2006). Sustainable tourism using regulations, market mechanisms and green certification: a case study of Barbados. Journal of Sustainable Tourism, 14(5), 489-511. http://dx.doi.org/10.2167/jost600.0

Paik, Y., \& D. Choi, 2007. Control, Autonomy and Collaboration in the Fast Food Industry A Comparative Study between Domestic and International Franchising. International Small Business Journal, 25(5), 539-562.

Sethi, R., \& Nicholson, C. Y. (2001). Structural and contextual correlates of charged behavior in product development teams. Journal of Product Innovation Management, 18(3), 154-168. http://dx.doi.org/10.1111/1540-5885.1830154

Shane, S. A. (1996). Hybrid organizational arrangements and their implications for firm growth and survival: A study of new franchisors. Academy of Management Journal, 39(1), 216-234. http://dx.doi.org/10.2307/256637

Siebert, R. (2015). Entering new markets in the presence of competition: price discrimination versus cannibalization. Journal of Economics \& Management Strategy, 24(2), 369-389. http://dx.doi.org/10.1111/jems.12091

Szulanski, G., \& Jensen, R. J. (2006). Presumptive adaptation and the effectiveness of knowledge transfer. Strategic Management Journal, 27(10), 937-957. http://dx.doi.org/10.1002/smj.551

Szulanski, G., \& Jensen, R. J. (2008). Growing through copying: The negative consequences of innovation on $\begin{array}{lllll}\text { franchise network growth. Research } & \text { Policy, }\end{array}$ https://doi.org/10.1016/j.respol.2008.08.012

Tuncalp, S. (1991). The problems and prospects for franchising in the Arabian Peninsula: the case of Saudi 
Arabia. International Journal of Retail \& Distribution Management, 19(4). Doi: https://doi.org/10.1108/09590559110000637

Welsh, D. H., Alon, I., \& Falbe, C. M. (2006). An examination of international retail franchising in emerging markets. Journal of small Business management, 44(1), 130.

Xie, Y., Batra, R., \& Peng, S. (2015). An extended model of preference formation between global and local brands: The roles of identity expressiveness, trust, and affect. Journal of International Marketing, 23(1), 50-71.

\section{Copyrights}

Copyright for this article is retained by the author(s), with first publication rights granted to the journal.

This is an open-access article distributed under the terms and conditions of the Creative Commons Attribution license (http://creativecommons.org/licenses/by/4.0/). 